\title{
IMPACTS OF LAND COVER AND GREENHOUSE GAS (GHG) CONCENTRATION CHANGES ON THE HYDROLOGICAL CYCLE IN AMAZON BASIN: A REGIONAL CLIMATE MODEL STUDY
}

\author{
ROCHA, Vinícius Machado - vinicius@inpa.gov.br \\ Instituto Nacional de Pesquisas Amazônicas \\ CORREIA, Francis Wagner Silva - francis.wagner70@gmail.com \\ Instituto Nacional de Pesquisas Espaciais \\ SATYAMURTY, Prakki - saty.prakki@gmail.com \\ Instituto Nacional de Pesquisas Espaciais \\ FREITAS, Saulo Ribeiro de - sfreitas@cptec.inpe.br \\ Universidade de São Paulo \\ MOREIRA, Demerval Soares - demerval.moreira@cptec.inpe.br \\ Instituto Nacional de Pesquisas Espaciais \\ SILVA, Paulo Ricardo Teixeira da - paulo.ricardo.teixeira@gmail.com \\ Universidade Federal de Alagoas \\ FIALHO, Edson Soares - fialho@ufv.br \\ Universidade Federal de Viçosa
}

\begin{abstract}
The Brazilian Regional Atmospheric Modeling System (BRAMS) coupled with the dynamic vegetation scheme known as General Energy and Mass Transport Model (GEMTM) and land cover scenarios in the Amazon Basin and greenhouse gas concentration increase scenarios produced by Community Climate System Model of the National Center for Atmospheric Research are used to evaluate the impacts on the hydrological cycle of the Amazon Basin. The 2050 estimates of deforestation and the greenhouse gas concentration scenarios (A2) impact significantly the energy and moisture budgets. The dynamic structure of the atmosphere and consequently the moisture and mass convergence in the region are projected to be significantly different in 2050. The changes are more intense in the simulations with the combined effect of deforestation and greenhouse gas increase. In the deforestation scenario, a positive feedback is established in which changes in the regional circulation reduced the moisture convergence and precipitation in the region. In the increased greenhouse gas concentration scenario, with and without deforestation, a negative (positive) feedback is established in the rainy (dry) season in which the regional circulation changes (moisture convergence) are responsible for the reduction of precipitation. The results indicate that rapid destruction of the forest and the climate changes due to human activity can become irreversible, and that changes on hydrological cycle and perturbation in the complex relation between soil, plant and atmosphere can trigger significant changes in the ecosystems in the Amazon, once these systems do not present resilience or capacity to adapt to the magnitude of changes in the climate.
\end{abstract}

Key words: Amazon basin, Deforestation, GHG Scenarios, IPCC-AR4, BRAMS.

IMPACTOS NA COBERTURA VEGETAL E NAS MUDANÇAS DE CONCENTRAÇÃO DE GASES DE EFEITO ESTUFA (GEE) NO CICLO HIDROLÓGICO DA BACIA AMAZÔNICA: UM MODELO DE ESTUDO CLIMÁTICO REGIONAL

RESUMO: O modelo regional BRAMS (Brazilian Regional Atmospheric Modeling System) acoplado ao esquema de vegetação dinâmica General Energy and Mass Transport Model (GEMTM) e cenários de usos da terra na Amazônia e de aumento na concentração dos gases do efeito estufa na atmosfera produzidos a partir das simulações climáticas do Modelo de Circulação Geral Community Climate System Model (CCSM3), do National Center for Atmospheric Research (NCAR), são utilizados para avaliar os impactos no ciclo hidrológico da

$$
\text { Ano } 10 \text { - Vol. } 15 \text { - JUL/DEZ } 2014
$$


bacia amazônica. A projeção de desflorestamento para o ano de 2050 e cenário de emissão dos gases do efeito estufa (A2) afetam de forma significativa os balanços de energia e de água, a estrutura dinâmica da atmosfera e, consequentemente, a convergência de umidade e massa na bacia. As mudanças são mais intensas na simulação que existe o efeito combinando do desflorestamento e aumento dos gases do efeito estufa. No cenário de desflorestamento, o mecanismo de retroalimentação positivo é estabelecido, no qual as alterações na circulação regional reduziram a convergência de umidade e a precipitação na região. Nos cenários de aumento dos gases do efeito estufa, sem e com desflorestamento, o mecanismo de retroalimentação é negativo (positivo) na estação úmida (seca), no qual as mudanças na circulação regional também conduziram a redução na precipitação. Os resultados indicam que a rápida destruição da floresta e as mudanças no clima regional decorrente de ações antropogênicas podem tornar-se um processo irreversível, e que as mudanças no ciclo hidrológico e as perturbações na complexa relação solo-planta-atmosfera podem desencadear alterações significativas nos ecossistemas naturais da Amazônia, já que os mesmos não apresentam grande capacidade de adaptação à magnitude das mudanças no clima.

Palavras-chaves: Amazônia, desflorestamento, cenários de emissões, IPCC-AR4, BRAMS.

\section{INTRODUCTION}

The Amazon jungle is the largest tropical forest on Earth and has $7.10^{6} \mathrm{~km}^{2}$ area, of which $5.10^{6} \mathrm{~km}^{2}$ are in Brazil. The Brazilian Amazon is $56 \%$ of the total tropical forest area of the globe. The Amazon forest is entirely in the tropics where the exchange of energy, moisture and mass at the surface are very intense, providing a long list of environmental services such as maintenance of biodiversity, storage and absorption of excess $\mathrm{CO}_{2}$ atmospheric, recycling of fresh water, supply of moisture to the surrounding regions, and in this way, maintaining the climate on the regional and global scales (ROCHA et al., 2004; FEARNSIDE, 2005; MALHI et al., 2008; DAVIDSON et al., 2012). Due to its great horizontal extension, the Amazon forest plays an important role in the $\mathrm{CO}_{2}$ and water global balance (GRACE et al., 1996; COX et al., 2004; MARENGO, 2006a; DAVIDSON et al., 2012). Recent measurements during the Large-scale Biosphere Atmosphere Experiment (LBA, AVISSAR and NOBRE, 2002) strongly indicate that the Amazon forest undisturbed functions as a sink of atmospheric $\mathrm{CO}_{2}$ (0.49 to $\left.0.79 \mathrm{PgC} \mathrm{year}^{-1}\right)$, especially in more fertile areas in the western Amazonia where the dry season is short (PHILLIPS et al., 2008).

The Amazon basin acts as a sink of atmospheric water vapor receiving water vapor transported from the Tropical Atlantic (MARENGO, 2005 e 2006a). The basin also recycles a part of the soil water by means of evapotranspiration by the vegetation (TRENBERTH, 1999). In the regional circulation context, the forest constitutes a source of water vapor for the central and southeastern regions of South America with an important role in the precipitation of these regions (MARENGO, 2004; VERA et al., 2006; ARRAUT and SATYAMURTY, 2009; SATYAMURTY et al., 2013). However, the forest is highly sensitive to the climate system variability, may it be due to natural causes or may it be due to anthropogenic reasons such as increasing the greenhouse gas (GHG) concentration by deforestation and biomass burning, fossil fuel burning or agricultural activity (OYAMA and NOBRE, 2003; COX et al., 2004; MARENGO, 2006b; D'ALMEIDA et al., 2007; BETTS et al., 2008; MALHI et al., 2008; COSTA and PIRES, 2010).

Deforestation and subsequent land use in the Amazon basin reached an alarmingly large area, $600.000 \mathrm{~km}^{2}$, which is approximately $15 \%$ of the total area of the original forest, at an average rate of $17.000 \mathrm{~km}^{2}$ year $^{-1}$ in the period $1988-2010$ (INPE, 2010). According to D'Almeida et al. (2007) the deforestation may lead to 
contrasting affects on the climate, depending on the spatial scale of the changes in the vegetation cover. In the small scale deforestation scenario the precipitation increases and in the large scale deforestation scenario it decreases, as is observed in the modeling studies (BAIDYA ROY and AVISSAR, 2002). One important question is the effect of global climatic changes on the ecosystems of the Amazon Basin. The global warming due to increase of greenhouse gases can lead to changes in the vegetation patterns (OYAMA and NOBRE, 2004; NOBRE et al., 2004). Several experiments with the general circulation models (GCM) indicate that the natural ecosystems do not present capacity to quickly adapt to climate change in the short time scale of decades (SCHOLZE et al., 2006; SALAZAR et al., 2007).

Although there is a degree of uncertainty in the results of the general circulation models and the coupled ocean-atmosphere models, they are important for the simulations of the current climate and future scenarios. It is known that the uncertainty is higher for regional scales. The principal disadvantage of the global models is the resolution, often with grid spacing of $100 \mathrm{~km}$ in the horizontal, which cannot properly take into account the mesoscale forcing (complex topography, vegetation cover, rivers and lakes) and physical processes such as radiation, convection, turbulence, cloud and rain microphysics (NICOLINI et al., 2002; MCPHERSON, 2007). This way, mapping of the large scale information generated by global circulation models (GCMs) on to the grid of the regional models, known as dynamic downscaling, using regional climate models that permit larger spatial and temporal resolution becomes a useful tool for studying climatic fluctuations and variability on the regional scale.

The synergy between alterations in the land use and the global climate changes raises an important question debated by the scientific community: In what way the changes in the land use and the climate can modify the hydrological cycle of the Amazon basin. In the light of the foregoing, the objective of the present study is to assess the impact of land cover change (LCC) and increase in greenhouse gas (GHG) concentration on the hydrological cycle in Amazonia using the regional model GEMBRAMS: Brazilian Regional Atmospheric Modeling System (BRAMS) coupled with the dynamic vegetation scheme General Energy and Mass Transport Model (GEMTM) and deforestation scenarios and GHG concentration scenarios for current and potential future conditions obtained from the Community Climate System Model (CCSM3) of the National Center for Atmospheric Research (NCAR).

\section{METHODOLOGY}

\subsection{The BRAMS regional model}

The numerical simulations are performed with the limited area model GEMBRAMS: BRAMS (Brazilian Regional Atmospheric Modeling System) version 4.2 (FREITAS et al., 2007) coupled with the General Energy and Mass Transport Model GEMTM dynamic vegetation scheme (CHEN and COUGHENOUR, 1994). The BRAMS 4.2 is designed to simulate the atmospheric systems on several scales; however it is frequently used to simulate mesoscale systems. Based on the complete set of nonhydrostatic primitive equations, the model includes state-of-the-art parameterization schemes for the micro and mesoscale physical processes. The model is developed using finite different schemes for the space and time integrations and is written in FORTRAN 90. The spatial grid is staggered Arakawa Type C (MESSINGER and ARAKAWA, 1976). The turbulent diffusion scheme is of Mellor and Yamada (1982); the parameterization of deep convection is of Grell and Dévènyi (2002); the radiation 
scheme is of Chen and Cotton (1983); the microphysical parameterization is as described in Walko et al., (1995); the momentum, and sensible/latent heat fluxes and radiation fluxes between the vegetated surface and the atmosphere are determined by the Land Ecosystem-Atmosphere Feedback Model - LEAF version 3 (WALKO et al., 2000).

\subsection{The GEMTM dynamic vegetation model}

The version used in this study contains a module called General Energy and Mass Transport Model (GEMTM), which simulates the interaction between the surface and the atmosphere in a two-way dynamic mode (CHEN and COUGHENOUR, 1994; PITMAN and NARISMA, 2005; BELTRÁN-PRZEKURAT et al., 2008). In contrast to other land-surface models, the GEMTM successfully linked leaf-level processes, canopy microclimate, soil abiotic processes, plant growth and biomass production dynamics. The model GEMTM simulates the physical and biological short period processes such as turbulent exchange between the canopy and the atmosphere, radiative transfer and interception, photosynthesis for the plants type $C_{3}$ and $C_{4}$ and stomatal conductance; and also the ecosystem response processes (long period) such as plant growth and dynamics of vegetation.

\subsection{Experiment design and scenarios}

Four numerical experiments are performed: CNTRL, CEDES, CA2S50, CA2D50. In CNTRL a representation of the vegetation of the whole Amazon Basin, elaborated by the Project ProVeg (SESTINI et al., 2002) considering the deforestation data for the base year 2000 (INPE, 2010), and the current scenario of the greenhouse gas (GHG) emissions obtained from the atmospheric model CCSM3 (NCAR) are considered. In the CEDES experiment, the deforestation scenario projected for the year 2050 for the Amazon basin, elaborated by dynamic vegetation model, and the current scenario of the emissions are considered. In the experiments CA2S50 and CA2D50 the future emission scenario A2 for the year 2050 is utilized. However, in the simulation CA2D50 the deforestation scenario projected for 2050 is used, and in the CA2S50 deforestation data corresponding to the year 2000 is used. Each experiment comprises of three integrations (ensemble) for 14 months starting from 00:00 UTC of 01 November with CCSM3 analysis as the initial condition. The initial soil moisture condition is obtained from Gevaerd and Freitas (2006). Sea surface temperature (SST) values were taken from the coupled ocean-atmosphere model (CCSM3) monthly means. The model is configured with a single grid resolution of $40 \mathrm{~km}$ and 32 levels in the vertical over the domain $15^{\circ} \mathrm{N}-50^{\circ} \mathrm{S}$ and $25^{\circ} \mathrm{W}-90^{\circ} \mathrm{W}$ (Table 1 ). The model assimilated the analyses produced by CCSM3 every 6 hours through dynamic downscaling process. In the regional GEMBRAMS model, the GHG concentrations for the current and future climates were equal and were maintained constant during the numerical integration. The first month output is ignored and the outputs of the remaining 13 months are analyzed.

Table 1 - Characteristics of the numerical simulations in each experiment using the regional model GEMBRAMS. ${ }^{(*)}$ See Nakicenovic et al. (2000) and Pitman and Narisma (2005). 


\begin{tabular}{lccccc}
\hline Experiment & Initialization & Simulations & Downscaling & $\begin{array}{c}\text { Climate } \\
\text { Scenario }\end{array}$ & $\begin{array}{c}\text { Deforestation } \\
\text { Scenario }\end{array}$ \\
\hline CNTRL & $1,2,3 / 11 / 1999$ & 14 Months & CCSM3 & 2000 current & $2000-$ ProVeg \\
CEDES & $1,2,3 / 11 / 1999$ & 14 Months & CCSM3 & 2000 current & $2050-$ DINAMICA \\
CA2S50 & $1,2,3 / 11 / 2049$ & 14 Months & CCSM3 & $2050-$ A2 & $2000-$ ProVeg \\
CA2D50 & $1,2,3 / 11 / 2049$ & 14 Months & CCSM3 & $2050-$ A2 & $2050-$ DINAMICA \\
\hline
\end{tabular}

Table 1 - Continuation.

\begin{tabular}{llccc}
\hline Experiments & SST & $\begin{array}{c}\text { Emission } \\
\text { Scenarios (CO }\end{array}$ ) & $\begin{array}{c}\text { Spatial } \\
\text { Resolution }\end{array}$ & Grid Size \\
\hline CNTRL & CCSM3 current & $369 \mathrm{ppmv}^{(*)}$ & $40 \mathrm{~km}$ & $150 \times 180$ \\
CEDES & CCSM3 current & $369 \mathrm{ppmv}^{(*)}$ & $40 \mathrm{~km}$ & $150 \times 180$ \\
CA2S50 & CCSM3 future & $532 \mathrm{ppmv}^{(*)}$ & $40 \mathrm{~km}$ & $150 \times 180$ \\
CA2D50 & CCSM3 future & $532 \mathrm{ppmv}^{(*)}$ & $40 \mathrm{~km}$ & $150 \times 180$ \\
\hline
\end{tabular}

\subsection{Deforestation and GHG emissions scenarios}

Two land use scenarios in Amazonia are considered: a) Current deforestation scenario, taking the 2000 as reference and b) Year 2050 scenario (Figure 1). In the current day scenario the vegetation map elaborated by the ProVeg Project (SESTINI et al., 2002) is used. This map is produced from the data obtained during RADAMBRASIL project that included 26 maps, at a 1:1.000.000 scale, and Instituto Brasileiro de Geografia e Estatística (IBGE, Brazilian Geography and Statistics Institute) vegetation land cover data, at a $1: 5,000,000$ scale (IBGE 1993), both available in digital format. Deforestation assessments conducted by Project Monitoring the Brazilian Amazon Gross Deforestation (INPE, 2010) have been used to include the anthropogenic land cover changes that have been occurring in the Amazon basin over the last several years. The assessments were based on Landsat Thematic Mapper (TM) satellite imagery analysis, of 112 scenes over the arc of deforestation (a region of intensive deforestation in the Legal Amazon) for base year 1997. The vegetation maps from IBGE and the RADAM project contain "contact" areas, which occur when two or three different vegetation types combine. 

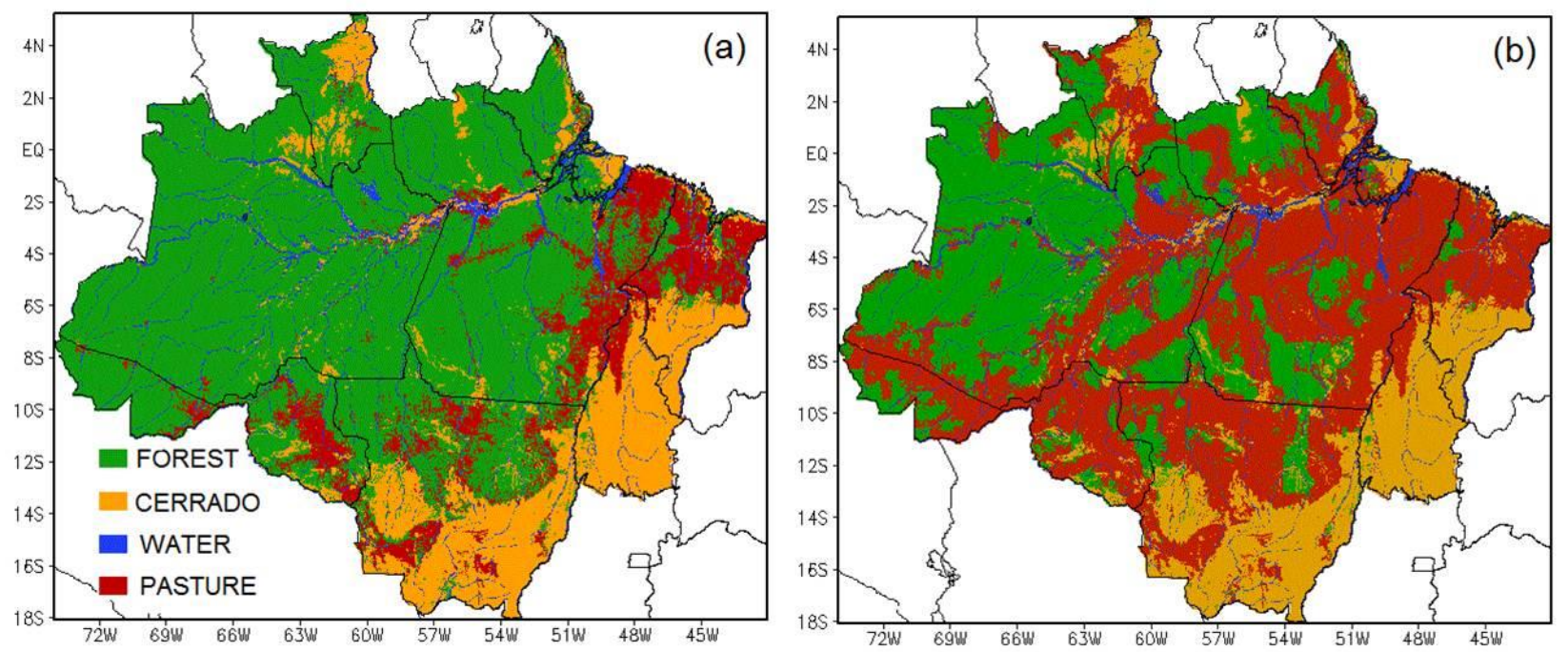

Figure 1 - Deforestation scenarios with a horizontal resolution of $1 \mathrm{~km}$. (a) current deforestation scenario produced by the ProVeg Project (year 2000 as reference) and used in the control simulation; (b) deforestation scenario for 2050 used in the CEDES and CA2D50 experiments. On the map, green means tropical forest; yellow cerrado (a type of savanna); blue water, and red degraded pasture means deforested areas.

The scenario of the 2050 year is elaborated from the dynamic vegetation model Dinamica EGO (SOARES-FILHO et al., 2004). In this study the biome degraded pasture represented the deforestation in the Amazon Basin (CORREIA et al., 2008). Many parameters have been calibrated using measurements taken on forest and pasture sites in the Amazon region (CORREIA et al., 2005). Two emissions scenarios obtained from the CCSM3-NCAR (MEEHL et al., 2006) were also used in this study. The first scenario corresponds to the current day conditions in terms of climate and the second scenario is future climate changes under the $A 2$ (high $\mathrm{CO}_{2}$ increase SRES: Special Report on Emissions Scenarios, IPCC-AR4; RANDALL et al., 2007) corresponding to the year 2050 .

\section{CONTROL SIMULATION}

Four different precipitation data-bases are used for the validation of precipitation simulated by the control experiment with regional GEMBRAMS model: a) Tropical Rainfall Measuring Mission - TRMM (KUMMEROW et al., 1998), b) MERGE (combined satellite precipitation estimates with surface observations over South America - VILA et al., 2009), c) Climatic Research Unit (CRU, NEW et al., 1999), and d) Climate Prediction Center (CPC) Merged Analysis of Precipitation (CMAP; XIE and ARKIN, 1997). For the validation of the performance of the model precipitation the mean monthly variation of precipitation for the period December 1999 - November 2000 was used. In general the model captured the seasonal and spatial (not showed) distribution of the maxima and minima during the wet season, especially the precipitation distribution associated with the South Atlantic Convergence Zone (SACZ). In the Amazon region the precipitation is underestimated by $3 \mathrm{~mm}$ day $^{-1}$ in dry season, and the performance is better in wet season. At the same time the simulated rainfall over the Northeast Brazil interior is higher than the observed. Systematic errors in the simulations are large over the Andes region, especially in the northern parts, due to topographic effects that are not well resolved by the model. In the dry season largest quantities of rainfall are observed over the extreme north of South America, eastern costal belt of the Northeast and in Southern regions of Brazil. Different weather systems are responsible for the precipitation over the three regions. The rainfall in the north is produced by tropical convection and the interaction 
between the continental warming and large-scale convergence. In the south the precipitation is caused by cold fronts that propagate from Argentina. The coastal Northeast receives rainfall by the organization of squall lines. In the northern portions of the continent and over the Andes the rainfall is overestimated by the regional model. However, climatology shows that the rainfall is usually abundant in the northern parts (FIGUEROA and NOBRE, 1990). The position of the ITCZ and the cloud band over the Atlantic Ocean near the coast are well produced but the rainfall is more than normal.

\section{RESULTS AND DISCUSSION}

The regional changes in temperature, precipitation, evapotranspiration and moisture convergence due to scenario changes obtained in the experiments CEDES, CA2S50 and CA2D50, are presented here. The changes are described in terms of the differences from the control scenario (CNTRL). The results are for the rainy season in the Amazon basin. In the deforestation scenario (CEDES), the surface temperature presented an increase of the order of $0.5^{\circ}-1.8^{\circ} \mathrm{C}$ (Figure 2b). Most significant values are observed in southern Amazonia, eastern Para, Rondonia and Roraima states of Brazil. The relation between the increase in surface temperature and deforestation along the highways Belem-Brasilia, Cuiaba-Porto Velho, Manaus-Porto Velho is well indicated in the simulation. These values are close to those obtained by Correia et al. (2008) where the authors evaluated the climate changes due to deforestation using the limited area ETA model. Numerical simulations with global circulation and regional model performed by Lean and Rowntree (1997) and Gandu et al. (2004), respectively, have shown less significant increase, in the surface temperature, than obtained here. Most studies used the physical parameters of savanna to represent the deforested areas in the tropics while the present study used the parameters of the degraded pasture in Amazonia (CORREIA et al., 2005). Moreover, most models used in the earlier studies did not represent dynamic vegetation in their surface schemes. The warming extended from the surface to the planetary boundary layer ( $P B L$ ), principally in southern Amazonia and Rondonia state, with an increase of $0.4^{\circ} \mathrm{C}$ at the top of the layer (not shown). The warming over the deforested land is the result of the reduction in evapotranspiration and reduction in the surface roughness. The roughness has an important role in the modulation of the turbulent fluxes of heat and moisture between the surface and the overlying air. The reduction in roughness length reduced the turbulent transfer efficiency of the energy at the surface, thus a higher temperature is necessary to remove the excess heat from the surface. Moreover, lower leaf area index and reduced soil moisture storage capacity in the degraded pasture have the effect of reducing the transpiration rate. Also, in the pasture less precipitation is intercepted and re-evaporated when the roughness length is relatively lower. 

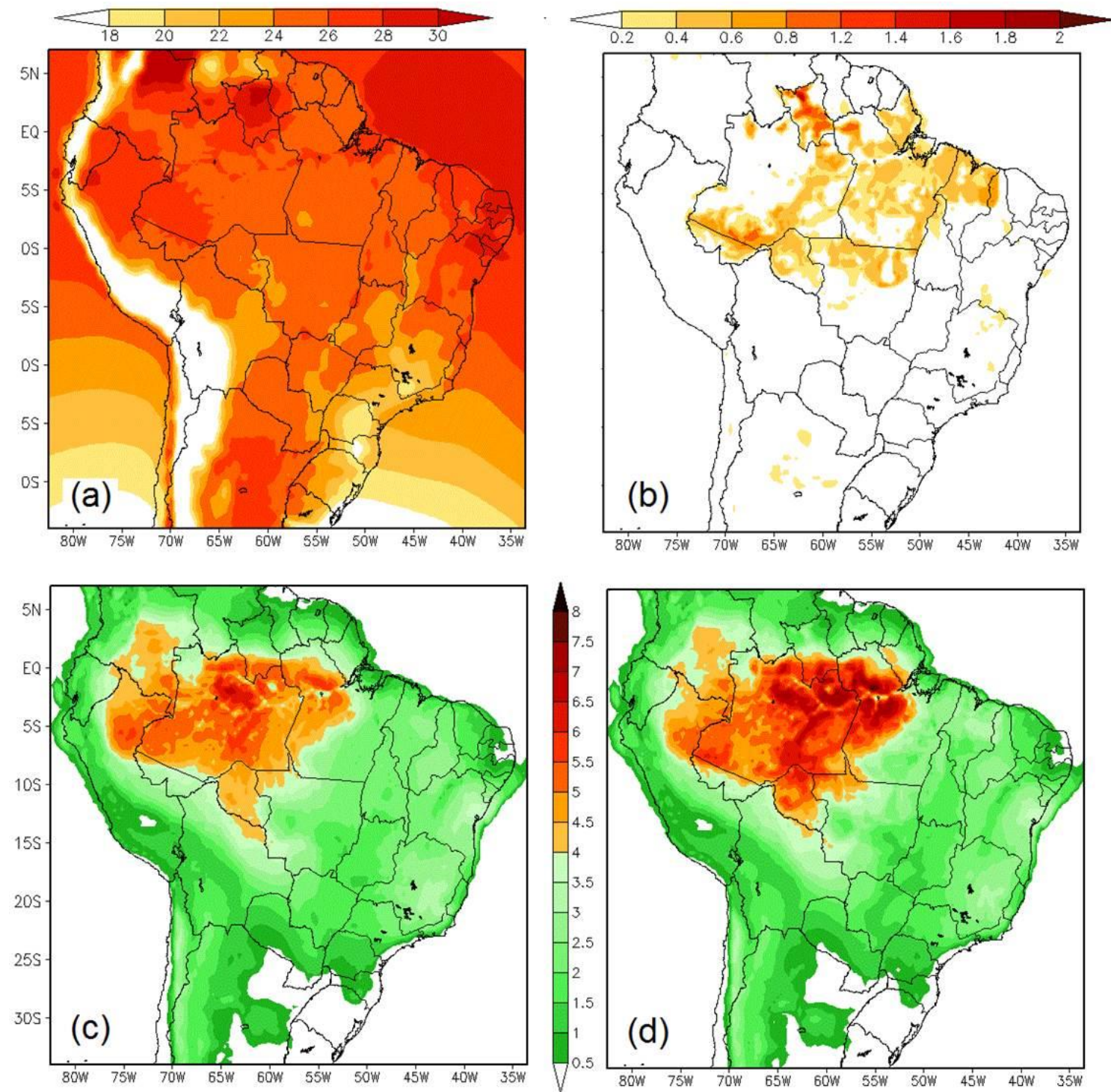

Figure 2 - Regional patterns of modeled surface temperature $\left({ }^{\circ} \mathrm{C}\right)$. (a) Control simulation wet season (CNTRL). Modeled wet season mean differences: (b) CEDES-CNTRL; (c) CA2S50-CNTRL; (d) CA2D50CNTRL.

The differential rate of warming in the PBL due to continental surface heterogeneity can lead to atmospheric circulations in different time and spatial scales. Different numerical and analytical studies have shown that the heterogeneities in the latent heat and sensible heat fluxes at the surface can produce strong mesoescale circulations (WANG et al. 1998). These circulations affect significantly the structure of the PBL, the heat and moisture fluxes (LYNN et al., 1995) and the organization of the clouds (WETZEL et al., 1996; RABIN and MARTIN, 1996). The energy, moisture and momentum exchanges between the surface and the atmosphere are important components of the climatic system; therefore, due the changes in these fluxes, mesoscale circulations caused by natural and anthropogenic surface heterogeneity affect significantly the general circulation (PIELKE et al., 1998).

Besides the deforestation, another worrying factor that can affect the climate, and the moisture budget in the Amazon Basin, is the global climatic changes due to an increase in the greenhouse gas concentration (GHG) in the atmosphere. Several experiments using the coupled climate system models have shown that the increase in their concentration modifies the radiative balance and energy balance as well as 
precipitation and temperature of the earth's climate system (BOUNOUA et al., 1999; COSTA and FOLEY, 2000; MARENGO, 2006b; RANDALL et al., 2007; ALLAN, 2011; MIN et al., 2011). In the CA2S50 scenario, the surface temperature presented positive anomalies of the order of $3.0^{\circ} \mathrm{C}$ to $6^{\circ} \mathrm{C}$ in some places in the Amazon basin, principally in the west-central portions of the region (Figure $2 \mathrm{c}$ ). Similar results were obtained by Ambrizzi et al. (2007) when the climate changes were evaluated in South America for the XXI century using three regional models, ETA-CPTEC/INPE, RegCM3 and HadRM3P, and with two emission scenarios: $A 2$ (high $\mathrm{CO}_{2}$ increase) and $\mathrm{B} 2$ (moderate $\mathrm{CO}_{2}$ increase). The authors found positive surface temperature anomalies higher than $2.0^{\circ} \mathrm{C}$ all over the continent, with extremes in the northern portions of the continent. In particular, the regional model ETA-CPTEC/INPE presented the highest impacts in the Amazon basin.

The increase in temperature is directly associated with the changes in the radiative balance at the surface and consequent changes in energy balance of the system (Figure 3). Another important effect, not applicable to the present study but observed in other studies, is associated with the dependence of the vegetationatmosphere interaction processes on the concentration of $\mathrm{CO}_{2}$, named the "physiological effect" (BOUNOUA et al., 1999; COSTA and FOLEY, 2000). In the last few decades several experiments were performed to evaluate the impacts of the increase in $\mathrm{CO}_{2}$ concentration on the global climate. In the majority of the studies the impacts of $\mathrm{CO}_{2}$ increase have taken into account the radiative effects only, ignoring the physiological effects. According to Costa and Foley (2000) the physiological response to increase in atmospheric $\mathrm{CO}_{2}$ concentration, resulting principally due to the dependence between photosynthesis (and stomatal conductance) and partial pressure $\mathrm{CO}_{2}$ effect, can potentially affect the climate (COLLATZ et al., 1992; SELLERS et al., 1996). 

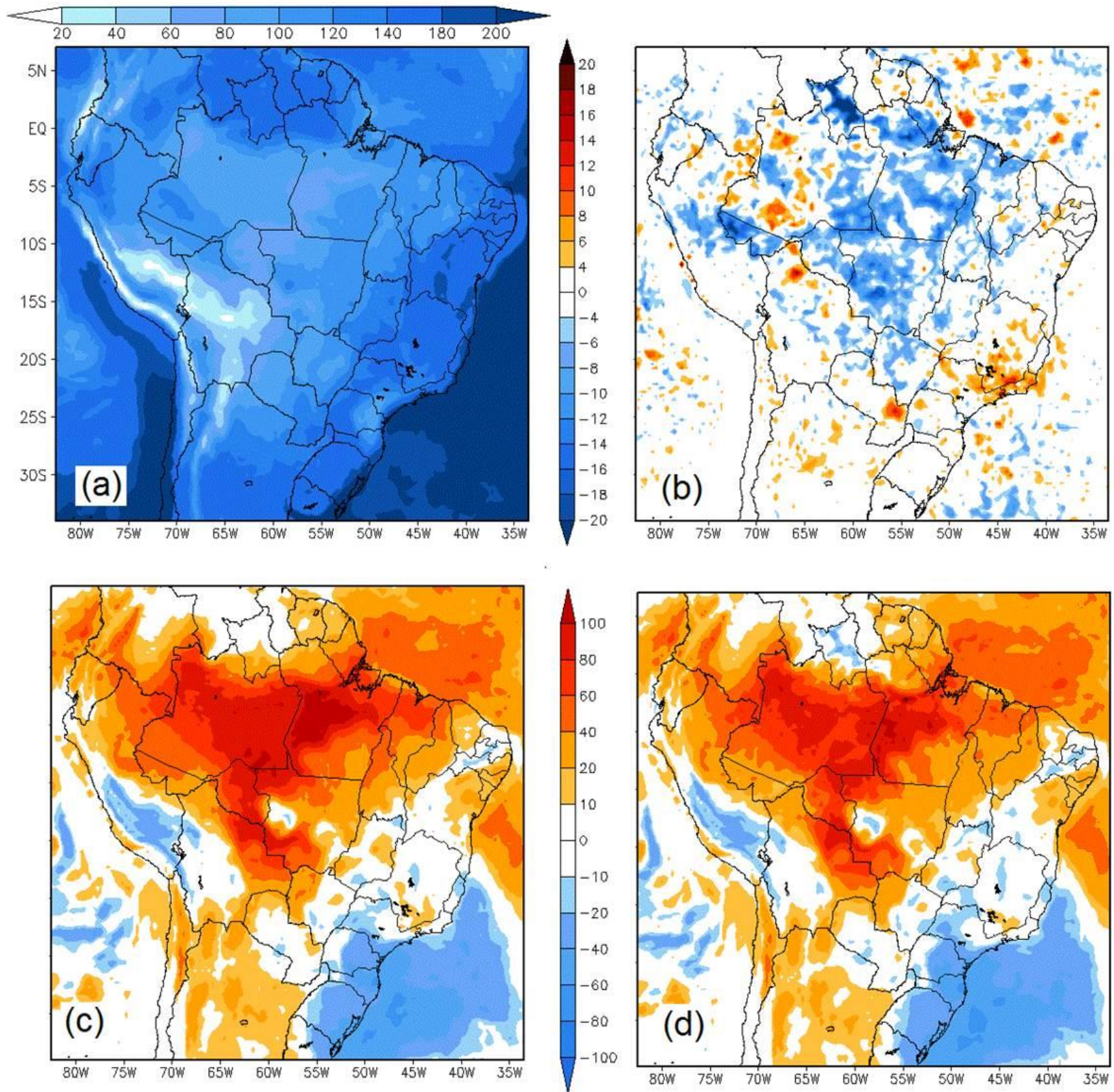

Figure 3 - Regional patterns of modeled net radiation $\left(\mathrm{W} \mathrm{m}^{-2}\right)$. (a) Control simulation wet season (CNTRL). Modeled wet season mean differences: (b) CEDES-CNTRL; (c) CA2S50-CNTRL; (d) CA2D50CNTRL.

The CA2D50 scenario produced only the most significant changes in the surface temperature when compared to other experiments. Positive anomalies are obtained over the whole South American continent; however the changes over the Amazon basin are more intense, of the order of $4^{\circ}-8^{\circ} \mathrm{C}$. This result shows that the combined effect of deforestation and the increase in the GHG concentration, including the interactions among the processes, lead to a higher increase of the surface temperature. This is mainly caused by the availability of energy at the surface $\left(\mathrm{CO}_{2}\right.$ increase) and by the reduction of evapotranspiration (deforestation effects). In other words, the two changes acted in the same direction to increase the surface temperature. Costa and Foley (2000) used the atmospheric GCM known as GENESIS of NCAR, coupled with the Integrated Biosphere Simulator - IBIS (FOLEY et al., 1996), to evaluate the combined effect of large-scale deforestation and the increase in $\mathrm{CO}_{2}$ concentration. They found that those two effects acted concomitantly to increase the surface temperature by about $3.5^{\circ} \mathrm{C}$ in the Amazon region. 
Differently from many other experiments with GCMs including the deforestation in Amazon region, it is observed here that the deforestation does not produce a general reduction in rainfall everywhere over the basin. The deforestation scenario for 2050 (CEDES) presents reduction in precipitation in some regions and an increase in other regions, as is seen in Figure 5 . Significant reductions $\left.\left(>2 \mathrm{~mm}^{-1}\right)^{-1}\right)$ are observed in the costal belt regions of the basin and over the state of Amazonas. On the other hand, significant increases in precipitation are seen in southeastern parts of the basin where the deforestation is intense. Similar results were obtained by Walker et al. (2009) as they searched for the climate-tipping points in the Amazon basin resulting from deforestation. Using the Regional Atmospheric Modeling System (RAMS) they verified if the forest areas protected by law in Brazil are enough to avoid a climatic change catastrophe in Amazonia, and found that the rainfall decreased in the western portion of the region while it increased in the southern and southeastern portions of the basin. In the present study neither an increase nor a decrease in precipitation is observed in the Amazon basin as a whole. The increase in precipitation in the south-central parts of the basin was due to an increase in the convergence of water vapor $\left(+3.0 \mathrm{~mm} \mathrm{day}^{-1}\right.$ significant at $99 \%$ level), although the evapotranspiration is reduced over a large part of the basin $\left(-0,7 \mathrm{~mm} \mathrm{day}^{-1}\right)$, as is shown in Figures 4 and 6 . This result indicates that the deforestation in the CEDES contributed to modify the structure and dynamics of the atmosphere producing local circulations (mesoscale), caused by differential heating due to heterogeneity of the surface because the thermal and radiative characteristics of the vegetative cover are modified. Different studies using limited area models have shown that the differential heating of the PBL due to heterogeneity produces horizontal differences in the turbulent fluxes of heat and moisture that drive intense mesoscale circulations (CHEN and AVISSAR, 1994a,b; AVISSAR and LIU, 1996; SILVA DIAS and REGNIER, 1996; WANG et al. 1996; AVISSAR and SCHMIDT, 1998; WANG et al. 2000; WEAVER and AVISSAR, 2002). Silva Dias and Regnier (1996), using a mesoscale model to validate the fluxes obtained from field observations in the forest and pasture lands during the Anglo-Brazilian Amazonian Climate Observation Study - ABRACOS (GASH et al., 1996), observed the presence of the mesoscale circulations as a response to differential surface heating between the forest and the pasture. This circulation is a result of complex interactions between different vegetation covers, topography and the large-scale flow. A combination of these effects lead to increases in the magnitude and depth of the vertical motions, the horizontal gradients of temperature, winds and humidity, and the formation of a deeper mixing layer. According to the authors, given enough moisture and thermodynamic stability the convection can be triggered that affects the transports of moisture, heat and momentum, and consequently the precipitation (PIELKE et al., 1998; WANG et al., 2000). 

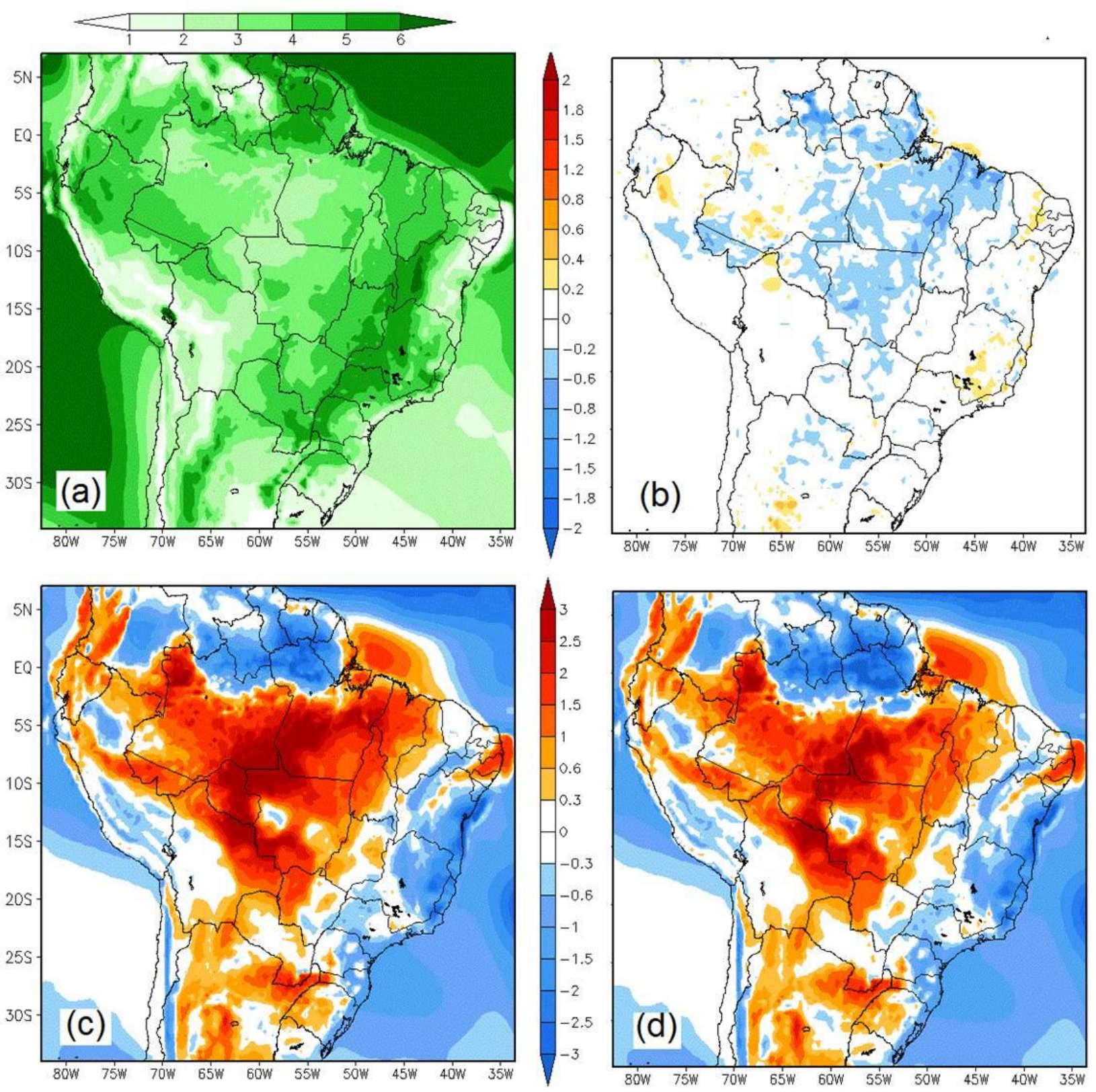

Figure 4 - Regional patterns of modeled evapotranspiration ( $\mathrm{mm} \mathrm{dia}^{-1}$ ). (a) Control simulation wet season (CNTRL). Modeled wet season mean differences: (b) CEDES-CNTRL; (c) CA2S50-CNTRL; (d) CA2D50-CNTRL.

In CA2S50, the increase in evapotranspiration (1.5 to $4 \mathrm{~mm} \mathrm{day}^{-1}$ ) over a large part of the basin is related to increased availability of energy at the surface (Figure 4). Changes in the precipitation are observed over almost the whole continent, with strong negative anomalies in the east-central portions and in the western parts of Nordeste ( -3 to $-5 \mathrm{~mm} \mathrm{day}^{-1}$ ). The South Atlantic Convergence Zone (SACZ) shifts southwards from its climatological position with positive precipitation anomalies larger than $4 \mathrm{~mm} \mathrm{day}^{-1}$ in South and Southeastern regions. In the southern region and some parts of the southeastern region of Brazil the precipitation increased significantly (Figure 5). In the region around the Low Level Jet (SALLJ), higher surface temperatures in the CA2S50 and CA2D50 scenarios intensified the low pressure center, leading to an acceleration of the jet, increasing the moisture convergence in the exit region of the jet, and as a result increasing the precipitation in the South and Southeastern regions. The Intertropical Convergence Zone is weaker and displaced to the north in the Tropical Atlantic. As a consequence the precipitations in Amazonia and Nordeste are reduced. Similar results were obtained by Marengo et al. (2006b) 
when they evaluated the changes in the climate in the XXI century using a climate model (HadCM3) of the Hadley Centre. According to the authors a situation in which the ITCZ is shifted slightly to the north and the intensification of the SACZ can be compared to an El Niño situation combined with warming of the Northern Atlantic. The reductions and increases of the precipitation in many places in Brazil indicate that the scenario CA2S50 led to changes in the thermodynamic structure of the atmosphere, changing the regional circulation patterns and the convergences in the lower troposphere. The reduction in the precipitation in central and eastern parts of Amazonia and the increase in the precipitation over the Southern and Southeastern Brazil regions are associated directly with the reduction and increase, respectively, in the convergence of moisture (Figure 6).
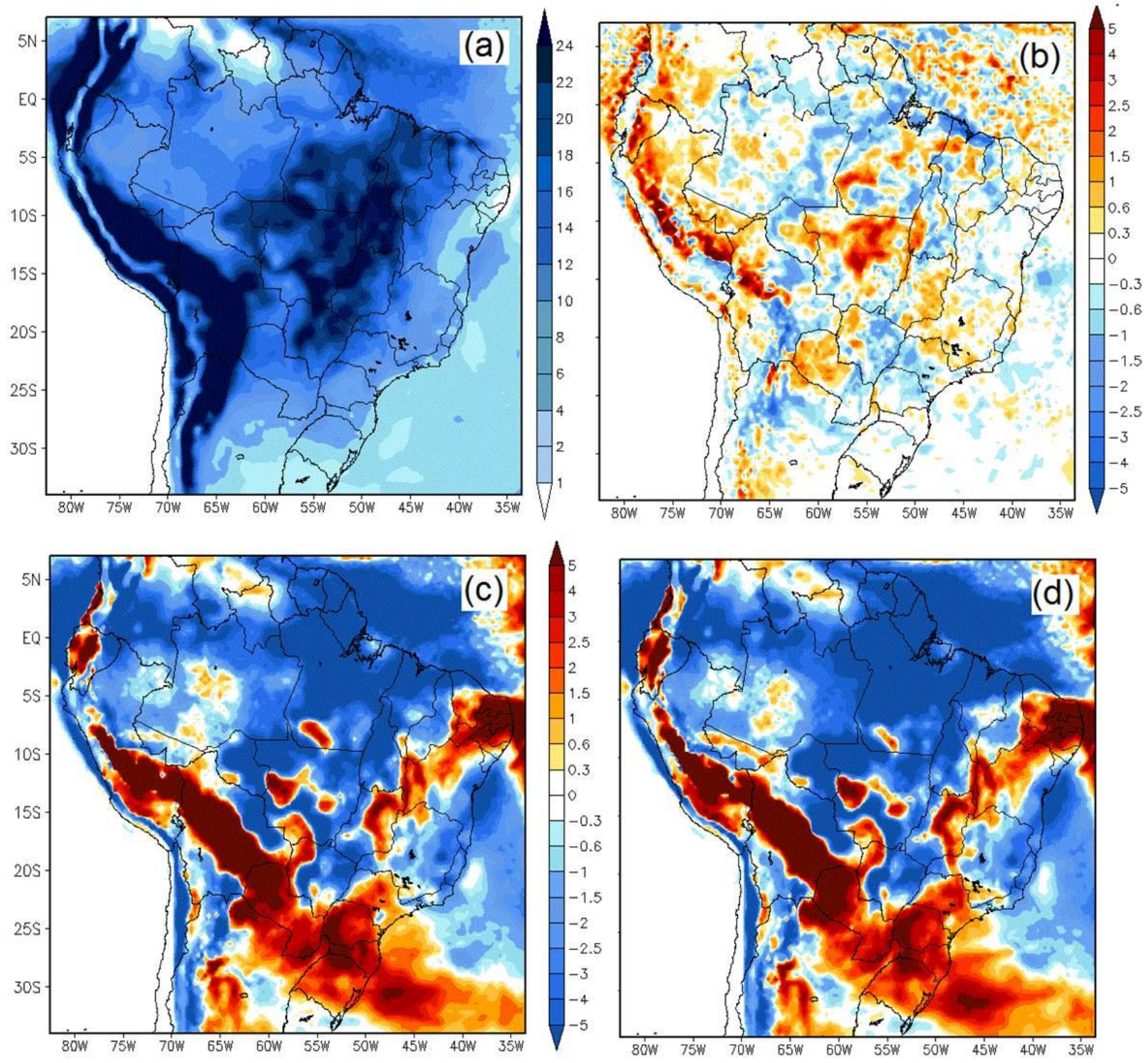

Figure 5 - Regional patterns of modeled precipitation $\left(\mathrm{mm} \mathrm{dia}^{-1}\right)$. (a) Control simulation wet season (CNTRL). Modeled wet season mean differences: (b) CEDES-CNTRL; (c) CA2S50-CNTRL; (d) CA2D50CNTRL.

The combined effect of deforestation and increased in GHG concentrations led to similar changes observed in the CA2S50 scenario, however acting more significantly on the intensity of rainfall. These changes in the precipitation were driven by the increase in GHG concentrations. The changes in precipitation are observed all 
over the continent with strong negative anomalies $\left(-1\right.$ to $\left.-4 \mathrm{~mm} \mathrm{dia}^{-1}\right)$ in the eastcentral portions of the Amazon basin. In the CA2D50 scenario also the SACZ is positioned to the south of its climatological position, and with positive anomalies of the order of 2-4 $\mathrm{mm} \mathrm{dia}^{-1}$ in South and Southeastern regions. In the Southern Brazil region and in some parts the adjoining Southeastern Brazil there is a significant increase $\left(+3.5 \mathrm{~mm} \mathrm{day}^{-1}\right)$ in the precipitation. Moreover, the ITCZ is less intense and shifted northward in the Tropical Atlantic. The reduction in the precipitation in central and eastern parts of Amazonia and the Tropical Atlantic is mainly due to the reduction in moisture convergence. The increase in the precipitation over Southeastern and Southern regions of Brazil is due to the increase in moisture convergence over the regions.
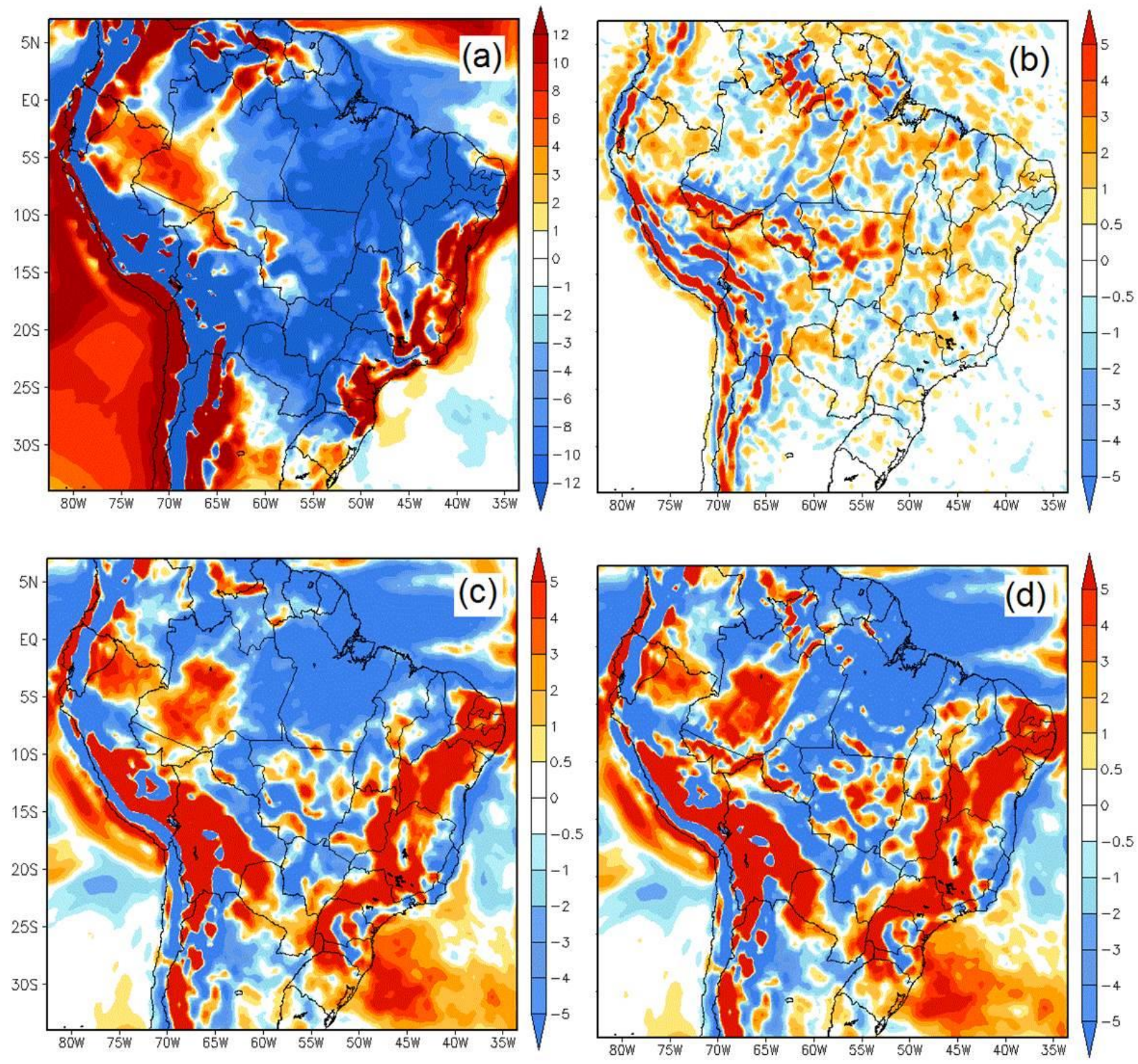

Figure 6 - Regional patterns of modeled moisture convergence ( $\mathrm{mm} \mathrm{dia}^{-1}$ ). (a) Control simulation wet season (CNTRL). Modeled wet season mean differences: (b) CEDES-CNTRL; (c) CA2S50-CNTRL; (d) CA2D50-CNTRL. 


\section{Summary and Conclusions}

A numerical modeling study with the GEMBRAMS: Brazilian Regional Atmospheric Modeling System - BRAMS coupled with the dynamic vegetation scheme General Energy and Mass Transport Model - GEMTM and scenarios associated with changes in land use in Amazonia and greenhouse gas emission scenarios obtained by the Community Climate System Model of the National Center for Atmospheric Research (CCSM3-NCAR) to evaluate the water budget in Amazonia is realized. The projected deforestation scenario for 2050 along with the GHG emissions scenarios affected significantly the water and energy budget, the dynamic structure of the atmosphere and consequently the moisture convergence and precipitation in the Amazon basin. The changes are stronger in the simulations with combined deforestation and increased GHG concentration scenarios. The deforestation contributed for an increase of $0.6^{\circ} \mathrm{C}$ in the surface temperature and a reduction of $8 \%$ in the precipitation in the dry season, but neither an increase nor a decrease in precipitation is observed in the Amazon Basin in the wet season. The reduction in precipitation is due to changes in evapotranspiration, in the regional circulation and moisture convergence over the basin. The increased GHG concentration scenario without deforestation led to a reduction of $29 \%$ in precipitation in the wet season and $10 \%$ in the dry season and an increase of surface temperature of $3.4^{\circ} \mathrm{C}\left(1.4^{\circ} \mathrm{C}\right)$ in the wet (dry) season. In the combined scenario (deforestation plus increased GHG concentration) the reduction in precipitation was $32 \%$ in both wet and dry seasons and an increase of $3.8^{\circ} \mathrm{C}\left(2.1^{\circ} \mathrm{C}\right)$ in the surface temperature in wet (dry) season. In the deforestation scenario the positive feedback mechanism is established, in which the circulation changes and moisture convergence changes led to a reduction in precipitation in Amazonia. In the other scenarios CA2D50 and CA2S50, the feedback mechanism presented different behaviors in the two seasons, positive in the dry season and negative in the wet season. In these scenarios too the changes in moisture convergence, due the changes in regional circulation, led to reduction in precipitation over Amazonia.

In all the scenarios the feedback mechanism presented a worrisome characteristic, that is, capable of producing instability of the system. Such an instability can trigger significant changes in the natural ecosystem of Amazonia, once the ecosystem does not have the capacity to adapt to the magnitude of the changes in a short span of time. These results show that a rapid deforestation due to anthropological pressure can make the process irreversible. The changes in the hydrological cycle and the perturbations in the complex relationship between soil, plant and atmosphere due to land cover change (LCC) and increase in greenhouse gas (GHG) concentration could be so intense that, once the forest is destroyed and regional climate changed, it cannot regenerate by itself.

\section{ACKNOWLEDGEMENTS}

The present study is part of the Master's Dissertation of the first author under the supervision of the second author. The first author thanks CAPES (Coordenação de Aperfeiçoamento de Pessoal de Nível Superior) and FAPEAM (Fundação de Amparo à Pesquisa do Estado do Amazonas), for financial support, and all authors thanks INPA (National Institute for Amazonia Research) and UEA (University of Amazonas State) for the facilities. The authors would like to thanks Dr. Britaldo Soares-Filho for a deforestation scenario for 2050 and Dra. Regina Alvalá for current deforestation scenario (Proveg Project). 


\section{REFERENCES}

AMBRIZZI, T.; da ROCHA, R.P.; MARENGO, J.A.; PISNITCHENKO, I.; ALVES, L.M.; FERNANDEZ, J.P.R. Cenários regionalizados de clima no Brasil e América do Sul para o Século XXI: Projeções de clima futuro usando três modelos regionais. Relatório $N^{\circ} 3$. Brasília, DF: Ministério do Meio Ambiente - MMA, Secretaria de Biodiversidade e Florestas - SBF, Diretoria de Conservação da Biodiversidade - DCBio, Mudanças Climáticas Globais e Efeitos sobre a Biodiversidade, Sub projeto: Caracterização do clima atual e definição das alterações climáticas para o território brasileiro ao longo do Século XXI, 2007. 108p.

ALLAN, R.P. Human influence on rainfall. Nature, v. 470, p. 344-345, 2011.

ARRAUT, J.R.; SATYAMURTY, P. Precipitation and water vapor transport in the Southern Hemisphere with emphasis on the South American region. Journal of Applied Meteorology and Climatology, v. 48, n. 9, p. 1902-1912, 2009.

AVISSAR, R.; NOBRE, C.A. Preface to special issue on the Large-Scale Biosphere-Atmosphere Experiment in Amazonia (LBA). Journal of Geophysical Research, v. 107, n. D20, p. 1-2, 2002.

AVISSAR, R.; LIU, Y. Three-dimensional numerical study of shallow convective clouds and precipitation induced by land-surface forcing. Journal of Geophysical Research, v. 101, p. 7499-7518, 1996.

AVISSAR, R.; SCHMIDT, T. An evaluation of the scale at which ground-surface heat flux patchiness affects the convective boundary layer using large-eddy simulations. Journal of the Atmospheric Sciences, v. 55, n. 16, p. 2666-2689, 1998.

BAIDYA ROY, S.; AVISSAR, R. Impact of land use/land cover change on regional hydrometeorology in Amazonia. Journal of Geophysical Research, v. 107, n. D20, p. 1-12, 2002.

BELTRÁN-PRZEKURAT, A.; PIELKE, R.A.; PETERS, D.P.C.; SNYDER, K.A.; RANGO, A. Modeling the effects of historical vegetation change on near-surface atmosphere in the northern Chihuahuan Desert. Journal of Arid Environments, v. 72, n. 10, p. 1897-1910, 2008.

BETTS, R.; SANDERSON, M.; WOODWARD, S. Effects of large-scale Amazon forest degradation on climate and air quality through fluxes of carbon dioxide, water, energy, mineral dust and isoprene. Phil. Trans. R. Soc. B., v. 363, p. 1873-1880, 2008.

BOUNOUA, L.; COLLATZ, G.J.; SELLERS, P.J.; RANDALL, D.A.; DAZLICH, D.A.; LOS, S.O.; BERRY, J.A.; FUNG, I.; TUCKER, C.J.; FIELD, C.B.; JENSEN, T.G. Interactions between Vegetation and Climate: Radiative and Physiological Effects of Doubled Atmospheric $\mathrm{CO}_{2}$. Journal of Climate, v. 12, p. 309-324, 1999.

CHEN, C.; COTTON, W.R. A one dimensional simulation of the stratocumulus capped mixed layer. Bound-Layer Meteorology, v. 25, p. 289-3321, 1983.

CHEN, D.X.; COUGHENOUR, M.B. GEMTM: a general model energy and mass transfer of land surfaces and its application at the fife sites. Agricultural and Forest Meteorology, v. 68, p. 145$171,1994$.

CHEN, F.; AVISSAR, R. The impact of land-surface wetness heterogeneity on mesoscale heat fluxes. Journal of Applied Meteorology, v. 33, p. 1323-1340, 1994a.

CHEN, F.; AVISSAR, R. Impact of land-surface moisture variability on local shallow convective cumulus and precipitation in large-scale models. Journal of Applied Meteorology, v. 33, p. 1382-1401, 1994b. 
COLLATZ, G.J.; RIBAS-CARBO, M.; BERRY, J.A. Coupled photosynthesis-stomatal conductance model for leaves of $\mathrm{C}_{4}$ plants. Aust. J. Plant Physiol., v. 19, p. 519-538, 1992.

CORREIA, F.W.S.; ALVALÁ, R.C.S.; MANZI, A.O.; GIELOW, R.; KUBOTA, P.Y. Calibração do "Simplified Simple Biosphere Model - SSiB" Para Áreas de Pastagem e Floresta na Amazônia com Dados do LBA. Acta Amazonica, v. 35, n. 2, p. 283-297, 2005.

CORREIA, F.W.S.; ALVALÁ, R.C.S.; MANZI, A.O. Modeling the impacts of land cover change in Amazonia: a regional climate model (RCM) simulation study. Theoretical and Applied Climatology, v. 93, n. 3-4, p. 225-244, 2008.

COSTA, M.H.; FOLEY, J.A. Combined effects of deforestation and doubled atmospheric $\mathrm{CO}_{2}$ concentrations on the climate of Amazonia. Journal of Climate, v. 13, p. 18-34, 2000.

COSTA, M.H.; PIRES, G.F. Effects of Amazon and Central Brazil deforestation scenarios on the duration of the dry season in the arc of deforestation. International Journal of Climatology, $v$. 30, p. 1970-1979, 2010.

COX, P.M.; BETTS, R.A.; COLLINS, M.; HARRIS, P.P.; HUNTINGFORD, C.; JONES, C.D. Amazonian forest dieback under climate-carbon cycle projections for the 21st century. Theoretical and Applied Climatology, v. 78, p. 137-156, 2004.

D'ALMEIDA, C.; VOROSMARTY, C.J.; HURTT, G.C.; MARENGO, J.A.; DINGMAN, S.L.; KEIM, B.D. The effects of deforestation on the hydrological cycle in Amazonia: a review on scale and resolution. International Journal of Climatology, v. 27, p. 633-647, 2007.

DAVIDSON, E.A.; ARAÚJO, A.C.; ARTAXO, P.; BALCH, J.K.; BROWN, I.F.; BUSTAMANTE, M.M.C.; COE, M.T.; DEFRIES, R.S.; KELLER, M.; LONGO, M.; MUNGER, J.W.; SCHROEDER, W.; SOARES-FILHO, B.S.; SOUZA Jr, C.M.; WOFSY, S.C. The Amazon basin in transition. Nature, v. 481 , p. 321-328, 2012.

FEARNSIDE, P.M. Deforestation in Brazilian Amazonia: History, Rates, and Consequences. Conservation Biology, v. 19, p. 680-688, 2005.

FIGUEROA, S.N.; NOBRE, C. Precipitations distribution over Central and Western Tropical South America. Climanálise-Boletim de Monitoramento e Análise Climática, v. 5, n. 6, p. 3648, 1990.

FOLEY, J.A.; PRENTICE, I.C.; RAMANKUTTY, N.; LEVIS, S.; POLLARD, D.; SITCH, S.; HAXELTINE, A. An integrated biosphere model of land surface processes, terrestrial carbon balance, and vegetation dynamics. Global Biogeochem. Cycles, v. 10, p. 603-628, 1996.

FREITAS, S.R.; LONGO, K.M.; SILVA DIAS, M.A.F.; CHATFIELD, R.; SILVA DIAS, P.L.; ARTAXO, P.; ANDREAE, M.O.; GRELL, G.; RODRIGUES, L.F.; FAZENDA, A.; PANETTA, J. The Coupled Aerosol and Tracer Transport model to the Brazilian developments on the Regional Atmospheric Modeling System (CATT-BRAMS). Part 1: Model description and evaluation. Atmos. Chem. Phys. Discuss., v. 7, p. 8571-8595, 2007.

IBGE (Fundação Instituto Brasileiro de Geografia e Estatística). Mapa de Vegetação do Brasil (Mapa Temático. Escala 1:500.000). Rio de Janeiro, RJ, 1993.

GANDU, A.W.; COHEN, J.C.P.; SOUZA, J.R.S. Simulation of deforestation in eastern Amazonia using a high-resolution model. Theoretical and Applied Climatology, v. 78, n. 1-3, p. 123-135, 2004.

GASH, J.H.C.; NOBRE, C.A.; ROBERTS, J.M.; VICTORIA, R.L. Amazonian Deforestation and Climate. Chichester: John Wiley \& Sons, 1996, p. 425-435. 
GEVAERD, R.; FREITAS, S.R. Estimativa operacional da umidade do solo para iniciação de modelos de previsão numérica da atmosfera. Parte I: Descrição da metodologia e validação. Revista Brasileira de Meteorologia, v. 21, n. 3, p. 1-15, 2006.

GRACE, J.; MALHI, Y.; LLOYD, J. The use of eddy covariance to infer the net carbon dioxide uptake of Brazilian rain forest. Global Change Biology, v. 2, n. 3, p. 209-217, 1996.

GRELL, G.A.; DÉVÈNYI, D. A Generalized Approach to Parameterizing Convection Combining Ensemble and Data Assimilation Techniques. Geophysical Research Letters, v. 29, n. 14, p. 38.1-38.4, 2002.

INPE (National Institute for Space Research). Monitoring the Brazilian Amazon forest by satellite: 2008-2009. São José dos Campos, Brazil, 2010.

KUMMEROW, C.; BARNES, W.; KOZU, T.; SHIUE, J.; SIMPSON, J. The tropical rainfall measuring mission (TRMM) sensor package. J. Atmos. Oceanic Technol., v. 15, p. 809-817, 1998.

LEAN, J.; ROWNTREE, P.R. Understanding the sensitivity of a GCM simulation of Amazonian deforestation to the specification of vegetation and soil characteristics. Journal of Climate, $v$. 10, p. 1216-1235, 1997.

LYNN, R.J.; SCHWING, F.B.; HAYWARD, T.L. The effect of the 1991-93 ENSO on the California Current System. CalCOFI Rep., v. 36, p. 57-71, 1995.

MALHI, Y.; ROBERTS, J.T.; BETTS, R.A.; KILLEEN, T.J.; LI, W.; NOBRE, C.A. Climate Change, Deforestation, and the Fate of the Amazon. Science, v. 319, p. 169-172, 2008.

MARENGO, J.A. Interdecadal variability and trends of rainfall across the Amazon basin. Theoretical and Applied Climatology, v. 78, p. 79-96, 2004.

MARENGO, J.A. Characteristics and spatio-temporal variability of the Amazon River Basin Water Budget. Climate Dynamics, v. 24, p. 11-22, 2005.

MARENGO, J.A. On the Hydrological Cycle of the Amazon Basin: a historical review and current state-of-the-art. Revista Brasileira de Meteorologia, v. 21, p. 1-19, 2006 a.

MARENGO, J.A. Mudanças Climáticas Globais e seus Efeitos sobre a Biodiversidade: Caracterização do Clima Atual e Definição das Alterações Climáticas para o Território Brasileiro ao longo do Século XXI. Ministério do Meio Ambiente - MMA, Secretaria de Biodiversidade e Florestas, Brasília, DF, 2006b, 163p.

MCPHERSON, R.A. A review of vegetation-atmosphere interactions and their influences on mesoscale phenomena. Progress in Physical Geography, v. 31, n. 3, p. 261-285, 2007.

MEEHL, G.A.; WASHINGTON, W.M.; SANTER, B.D.; COLLINS, W.D.; ARBLASTER, J.M.; HU, A.; LAWRENCE, D.M.; TENG, H.; BUJA, L.E.; STRAND, W.G. Climate Change Projections for the Twenty-First Century and Climate Change Commitment in the CCSM3. Journal of Climate, v. 19 , p. 2597-2616, 2006.

MELLOR, G.L.; YAMADA, T. Development of a turbulence closure-model for geophysical fluid problems. Reviews of Geophysics, v. 20, n. 4, p. 851-875, 1982.

MESINGER, F.; ARAKAWA, A. Numerical methods used in atmospheric models. GARP Publication Series - WMO/ICSU Joint Organizing Committee, v. 1, n. 17, p. 1-64, 1976.

MIN, S.K.; ZHANG, X.; ZWIERS, F.W.; HEGERL, G.C. Human contribution to more-intense precipitation extremes. Nature, v. 470, p. 378-381, 2011. 
NAKICENOVIC, N.; ALCAMO, J.; DAVIS, G.; DE VRIES, B.; FENHANN, J.; GAFFIN, S.; GREGORY, K.; GRUBLER, A.; JUNG, T.Y.; KRAM, T.; LA ROVERE, E.L.; MICHAELIS, L.; MORI, S.; MORITA, T.; PEPPER, W.; PITCHER, H.; PRICE, L.; RIAHI, K.; ROEHRL, A.; ROGNER, H.H.; SANKOVSKI, A.; SCHLESINGER, M.; SHUKLA, P.; SMITH, S.; SWART, R.; VAN ROOIJEN, S.; VICTOR, N.; DADI, Z. Special Report on Emissions Scenarios: A Special Report of Working Group III of the Intergovernmental Panel on Climate Change. Cambridge, U.K.: Cambridge University Press, 2000, 599p.

NEW, M.; HUME, M.; JONES, P. Representing twentieth century space-time climate variability: 1. Development of a 1961-1990 mean monthly terrestrial climatology. Journal of Climate, v. 12, p. 829-856, 1999.

NICOLINI, M.; SALIO, P.; KATZFEY, J.J.; MCGREGOR, J.L.; SAULO, A.C. January and July regional climate simulation over South American. Journal of Geophysical Research, v. 107, n. D22, p. 1-13, 2002.

NOBRE, C.A.; OYAMA, M.D.; OLIVEIRA, G.S.; MARENGO, J.A.; SALATI, E. Impacts of climate change scenarios for 2091-2100 on the biomes of South America. First CLIVAR International Conference, Clim. Var. and Predictability, Baltimore, Md., 2004, 21-25 June.

OYAMA, M.D.; NOBRE, C.A. A new climate-vegetation equilibruim state for Tropical South America. Geophysical Research Letters, v. 30, n. 23, p. 1-4, 2003.

OYAMA, M.D.; NOBRE, C.A. A simple potential vegetation model for coupling with the simple biosphere model (SIB). Revista Brasileira de Meteorologia, v. 1, n. 2, p. 203-216, 2004.

PHILLIPS, O.; BAKER, T.; LEWIS, S.; CHAO, K.; HIGUCHI, N. The changing Amazon forest. Phil. Trans. R. Soc. B., v. 363, p. 1819-1827, 2008.

PIELKE, R.; AVISSAR, R.; RAUPACH, M.; DOLMAN, A.; ZENG, X.; DENNING, A. Interactions between the atmosphere and terrestrial ecosystems: Influence on weather and climate. Global Change Biology, v. 4, p. 461-475, 1998.

PITMAN, A.; NARISMA, G. The role of land surface processes in regional climate change: a case study of future land cover change over south western Australia. Meteorol. Atmos. Phys., v. 89 , p. $235-249,2005$.

RABIN, R.; MARTIN, D. Satellite observations of shallow cumulus coverage over the central United States: An exploration of land use impact on cloud cover. Journal of Geophysical Research, v. 101, p. 7149-7155, 1996.

RANDALL, D.A.; WOOD, R.A.; BONY, S.; COLMAN, R.; FICHEFET, T.; FYFE, J.; KATTSOV, V.; PITMAN, A.; SHUKLA, J.; SRINIVASAN, J.; STOUFFER, R.J.; SUMI, A.; TAYLOR, K.E. Climate Models and Their Evaluation. In: SOLOMON, S.; QIN, D.; MANNING, M.; CHEN, Z.; MARQUIS, M.; AVERYT, K.B.; TIGNOR, M.; MILLER, H.L. (Eds). Climate Change 2007: The Physical Science Basis. Contribution of Working Group I to the Fourth Assessment Report of the Intergovernmental Panel on Climate Change. Cambridge, United Kingdom and New York, NY, USA: Cambridge University Press, 2007, p. 590-662.

ROCHA, H.R.; GOULDEN, M.L.; MILLER, S.D.; MENTON, M.C.; PINTO, L.D.V.O.; FREITAS, H.B.; SILVA-FIGUEIRA, A.M. Seasonality of water and heat fluxes over a tropical forest in eastern Amazonia. Ecological Applications, v. 14, p. 822-832, 2004.

SALAZAR, L.F.; NOBRE, C.A.; OYAMA, M.D. Climate change consequences on the biome distribution in tropical South America. Geophysical Research Letters, v. 34, n. 9, p. 1-6, 2007. 
SATYAMURTY, P.; da COSTA, C.P.W.; MANZI, A.O. Moisture source for the Amazon Basin: a study of contrasting years. Theoretical and Applied Climatology, v. 111, n. 1-2, p. 195-209, 2013.

SCHOLZE, M.; KNORR, W.; ARNELL, N.W.; PRENTICE, I.C. A climate change risk analysis for world ecosystems. Proc. Natl. Acad. Sci. U.S.A., v. 103, n. 35, p. 13116-13120, 2006.

SELLERS, P.J.; BOUNOUA, L.; COLLATZ, G.J.; RANDALL, D.A.; DAZLICH, D.A.; LOS, S.O.; BERRY, J.A.; FUNG, I.; TUCKER, C.J.; FIELD, C.B.; JENSEN, T.G. Comparison of radiative and physiological effects of doubled atmospheric $\mathrm{CO}_{2}$ on climate. Science, v. 271, p. 1402-1406, 1996.

SESTINI, M.F.; ALVALÁ, R.C.S.; MELLO, E.M.K.; VALERIANO, D.M.; CHOU, S.C.; NOBRE, C.A.; PAIVA, J.A.C.; REIMER, E.S. Elaboração de mapas de vegetação para utilização em modelos meteorológicos e hidrológicos. Instituto Nacional de Pesquisas Espaciais (INPE), São José dos Campos, SP, Brasil, 2002, 74p.

SILVA DIAS, M.A.F.; REGNIER, P. Simulation of mesoescale circulations in a deforested area of Rondônia in dry season. In: GASH, J.H.C.; NOBRE, C.A.; ROBERTS, J.M.; VICTORIA, R.L. (eds.). Amazonian Deforestation and Climate. Chichester: John Wiley \& Sons, 1996, p. 531547.

SOARES-FILHO, B.S.; ALENCAR, A.; NEPSTAD, D.; CERQUEIRA, G.; DIAZ, M.; RIVERO, S.; SOLÓRZANOS, L.; VOLL, E. Simulating the response of land-cover change to road paving and governance along a major Amazon highway: the Santarém-Cuiabá corridor. Global Change Biology, v. 10, p. 745-764, 2004.

TRENBERTH, K.E. Atmospheric moisture recycling: role of advection and local evaporation. Journal of Climate, v. 12, p. 1368-1381, 1999.

VERA, C.; BAEZ, J.; DOUGLAS, M.; EMANUEL, C.B.; ORSINI, J.A.M.; MEITIN, J.; NICOLINI, M.; NOGUES-PAEGLES, J.; PAEGLE, J.; PENALBA, O.; SALIO, P.; SAULO, C.; SILVA DIAS, M.A.F.; SILVA DIAS, P.; ZIPSER, E. The South American Low Level Jet Experiment. Bulletin of the American Meteorological Society, v. 87, n. 1, p. 63-77, 2006.

VILA, D.; GONÇALVES, L.; TOLL, D.; ROZANTE, J.R. Statistical Evaluation of Combined Daily Gauge Observations and Rainfall Satellite Estimates over Continental South America. Journal of Hydrometeorology, v. 10, p. 533-543, 2009.

WALKER, R.; MOORE, N.J.; ARIMA, E.; PERZ, S.; SIMMONS, C.; CALDAS, M.; VERGARA, D.; BOHRER, C. Protecting the Amazon with protected areas. Proc. Natl. Acad. Sci. U.S.A., v. 106, n. 26, p. 10582-10586, 2009.

WALKO, R.L.; COTTON, W.R.; MEYERS, M.P.; HARRINGTON, J.Y. New RAMS cloud microphysics parameterization Part I: the single moment scheme. Atmospheric Research, v. 38, p. 29-62, 1995.

WALKO, R.L.; BAND, L.E.; BARON, J.; KITTEL, T.G.F.; LAMMERS, R.; LEE, T.J.; OJIMA, D.; PIELKE, R.A.; TAYLOR, C.; TAGUE, C.; TREMBACK, C.J.; VIDALE, P.L. Coupled atmospherebiophysics-hydrology models for environmental modeling. Journal of Applied Meteorology, $v$. 39, n. 6, p. 931-944, 2000.

WANG, J.; BRAS, R.; ELTAHIR, A. A stochastic linear theory of mesoscale circulation induced by the thermal heterogeneity oh the land surface. Journal of the Atmospheric Sciences, v. 53, n. 22, p. 3349-3366, 1996. 
WANG, J.; BRAS, R.; ELTAHIR, A. Numerical simulation of nolinear mesoscale circulations induced by the thermal heterogeneities of land surface. Journal of the Atmospheric Sciences, v. 55 , p. $447-464,1998$.

WANG, J.; BRAS, R.; ELTAHIR, A. The impact of observed deforestation on the mesoscale distribution of rainfall and clouds in Amazonia. Journal of Hydrometeorology, v. 1, p. 267-286, 2000.

WEAVER, C.P.; AVISSAR, R. Atmospheric disturbances caused by human modification of the landscape. Bulletin of the American Meteorological Society, v. 82, n. 2, p. 269-281, 2002.

WETZEL, P.; ARGENTINI, S.; BOONE, A. Role of land surface in controlling daytime cloud amout: Two case studies in the GCIP-SW area. Journal of Geophysical Research, v. 101, p. 7359-7370, 1996.

XIE, P.; ARKIN, P.A. Global precipitation: A 17-year monthly analysis based on gauge observations, satellite estimates, and numerical model outputs. Bulletin of the American Meteorological Society, v. 78, p. 2539-2558, 1997. 